\title{
当教室15年間の入院患者統計
}

\author{
山本真一郎・板谷 知已・森 慶人 \\ 羽柴 基之・馬場 駿吉
}

\section{A Statistical Review of Hospitalized Patients Treated in Our Clinic during the Past 15 Years}

\author{
Shin-ichiro Yamamoto, Tomomi Itaya, Yoshito Mori, \\ Motoyuki Hashiba and Shunkichi Baba \\ (Nagoya City University Medical School)
}

\begin{abstract}
The records of hospitalized patients in the Department of Otorhinolaryngology, Nagoya City University Medical School between 1976 and 1990 were analyzed. The total unmber of patients was 4,448. The locations of the diseases were: 1,002 were in the pharynx (22,5\%), 895 in the nasal cavity and paranasal sinuses $(20,1 \%), 732$ in the ear $(16,5 \%), 550$ in the larynx $(12,4 \%), 475$ in the diseases of abnormality $(10,7 \%), 217$ in the trachea and esophagus (4,9\%), 202 in the oral cavity $(4,5 \%), 111$ in the salivary gland $(2,5 \%)$, and 264 in the face and neck and other areas $(5,9 \%)$.
\end{abstract}

Key words: statistical review, hospitalized patient, Nagoya City University

はじめに

1976年 1 月より1990年12月までの15年間にお ける当科の入院患者についての統計的観察を行 った。この期間は高度経済成長時代が終焉をと げ，社会全体としては比較的落ち着いていたも のの, 生活, 文化, 科学技術等は大きな変化や 進歩が見られた。医学界全体としての診断, 治 療技術の变革もめざましいものがあり, 我々耳 鼻咽喉科・頭頸部外科領域においても, 診療技 術, 取り扱ら疾患に大きな変化があった。本論 文は上記年間における全入院患者統計である. 再入院した場合は 2 名として数え, 延べ人数で 表し，一人の患者に加療した疾患が複数ある場 合は主疾患を採用した。

\section{結果及び考察}

入院患者数は4448名であり, 男性2734名, 女 性1714名と男性が多かった. 図 1 に疾患を部位 別に分類して示した．咽頭疾患が1002名（22.5 \%) と最も多く，次いで鼻副鼻腔疾患895名 $(20.1 \%)$, 耳疾患 732 名 $(16.5 \%)$ ，喉頭疾患 550 名 $(12.4 \%)$, 先天奇形 475 名 (10.7\%) の順にな っている. 全体的にバランスのとれた疾患構成 であると思われるが，強いて言えば先天奇形が やや多いことに特徵がある。なお，眩暈症は耳 疾患に分類した。

図 2 には, 悪性腫瘍を部位別に分類して示し た。悪性腫瘍は男性678名, 女性235名の合計 913名であり，総患者数の $20.5 \%$ 占めていた. 
喉頭悪性腫瘍が282名（30.9\%）と最も多く, 次いで咽頭悪性腫瘍204名 (22.3\%)，鼻副鼻腔 悪性腫瘍183名 (20.0\%)， 口腔悪性腫瘍152名 （16.6\%）と続いていた.

次に, 患者数の年次推移を図 3 に示した. 1981年までは年間約230名であったが，1982年 より300名以上に急増している。これは1981年 までは耳鼻咽喉科の病床数24床であったのに対 し，1982年からは病床数が40床に増えたことが 大きく影響していると考える。また，1988年よ り減少傾向が見られるが，これは1988年の病棟 工事による入院制限や，悪性腫瘍に対する治療 法の変遷による入院の長期化等が影響している と考光られる。

悪性腫瘍の年次別推移においても若干の増加

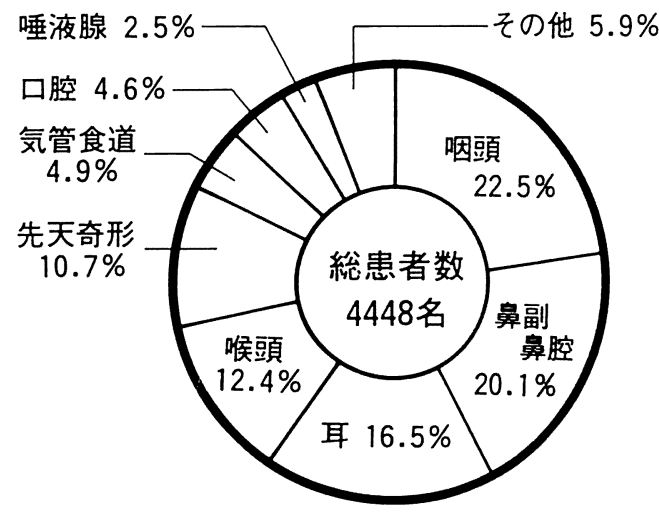

図 1 各疾患の割合

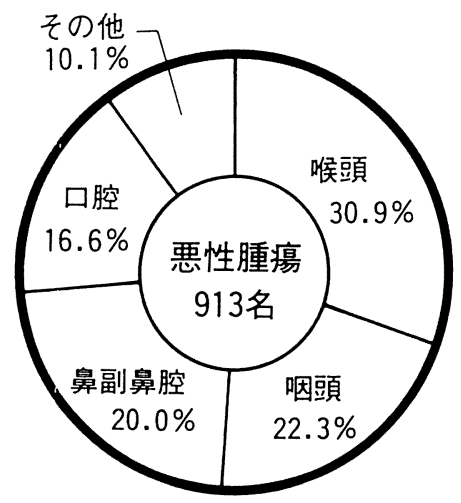

図 2 悪性腫瘍の部位別頻度
傾向にあった。

次に，頻度の順に従って部位別に主な疾患に ついて検討してみた.

\section{1 ) 咽頭疾患}

咽頭疾患の入院患者数は男性 600 名, 女性 402 名の合計1002名であった。このうち習慣性アン ギーナ，扁桃病巣感染症等により扁桃摘出術を 目的として入院した患者数が 612 名 $(61.1 \%)$ と過半数を占めていた．扁桃摘出術は近年減少

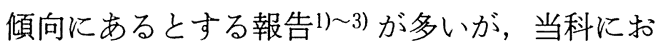
いては増減に関する一定の傾向は認めなかった．

図 4 に咽頭悪性腫瘍の年次推移を示した. 図のごとく年々増加傾向にあった。 また，図 5 には咽頭悪性腫瘍の年齢別性別分布を示したが， 男女比は3.5対 1 と男性に多く, 男性は50歳代, 女性は60歳代にピークがあった，近年増加傾向 にあることや男性に多いことは諸家4) 8) の報告 と同様であった。

咽頭悪性腫瘍の部位としては上咽頭悪性腫瘍 が77名と最も多く, 次いで下咽頭悪性腫瘍 65 名,

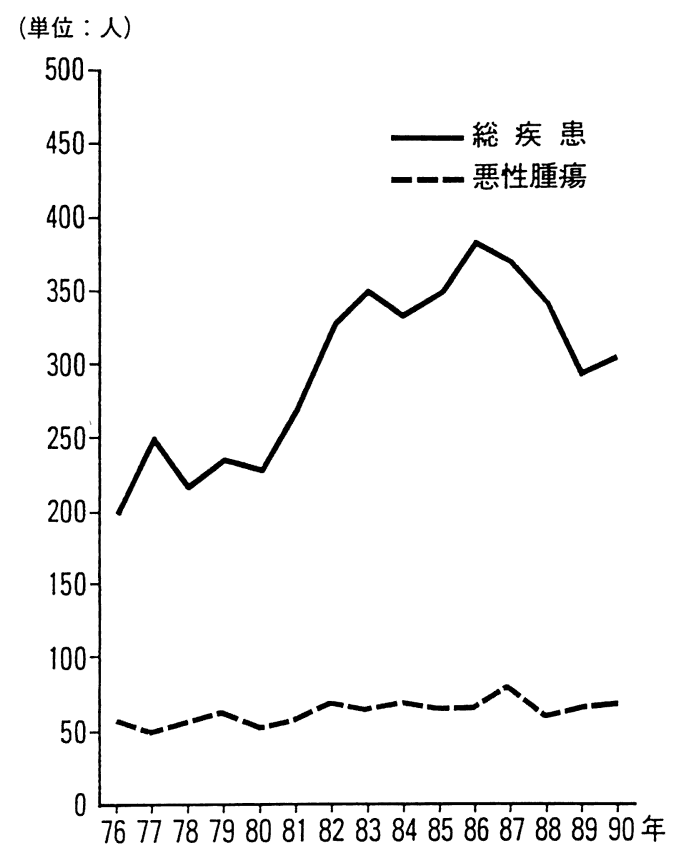

図 3 入院患者数年次推移 
中咽頭悪性腫瘍62名の順であり，また，これら の男女比は，それぞれ4.9対 1，3.1対 1，2.6 対 1 で，いずれも男性に多く，特に上咽頭悪性 腫瘍は男性が女性の約 5 倍と多かった。

2 ) 鼻副鼻腔疾患

鼻副鼻腔疾患の入院患者数は男性567名, 女 性310名の合計877名であった。このうち慢性副 鼻腔炎が293名（33.4\%）と最も多く，次いで 術後霊胞148名 (16.9\%), 上顎癌143名（16.3 \%), 鼻出血120名（13.7\%）と続いていた.

(単位：人)

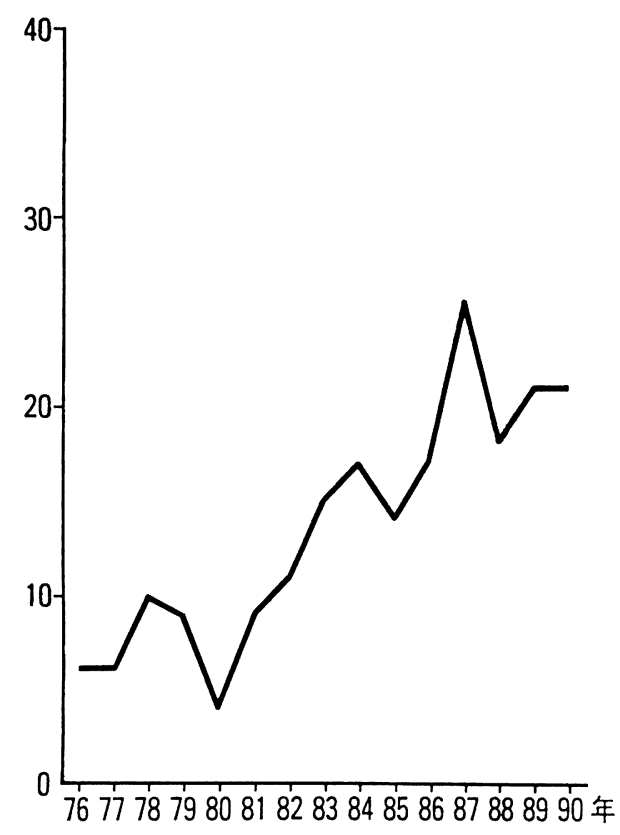

図 4 咽頭悪性腫瘍の年次推移

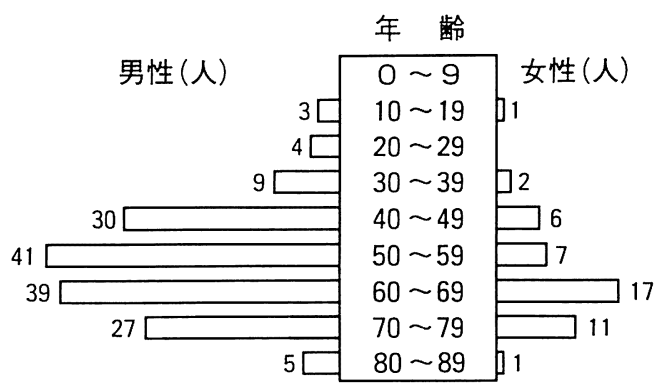

図 5 咽頭悪性腫瘍の年齡別性別分布
図 6 に慢性副鼻腔炎と上顎癌の年次推移を示 した．慢性副鼻腔炎は1982年より急増し，その 後1987年より減少している. この急増は病床数 の増加と一致している。つまり, 病床数の増加 により，入院の優先的な腫瘍性疾患を差し引い ての病床数の余剩に対応するものと考兄られる. また，1987年よりの減少は諸家の報告1) 319) に あるように，慢性副鼻腔炎自体の減少傾向を反 映していると思われる。

上顎癌に関しては特に増加あるいは減少傾向 はないとの報告が910) が見られるが，当科に沶 いては減少傾向にあった。 また，年齢及び性別 に関しては，男女比1.6対 1 で男性に多く，男 性が50～60歳代にピークがあるのに対し，女性 は40〜70歳代に幅広く分布していた。この点は, 女性のピークも60歳代に一峰性にあるという諸 家9110)の報告と若干異なる.

3 ) 耳疾患

耳疾患の入院患者数は男性362名, 女性369名 の合計731名であった。このうち慢性中耳炎が

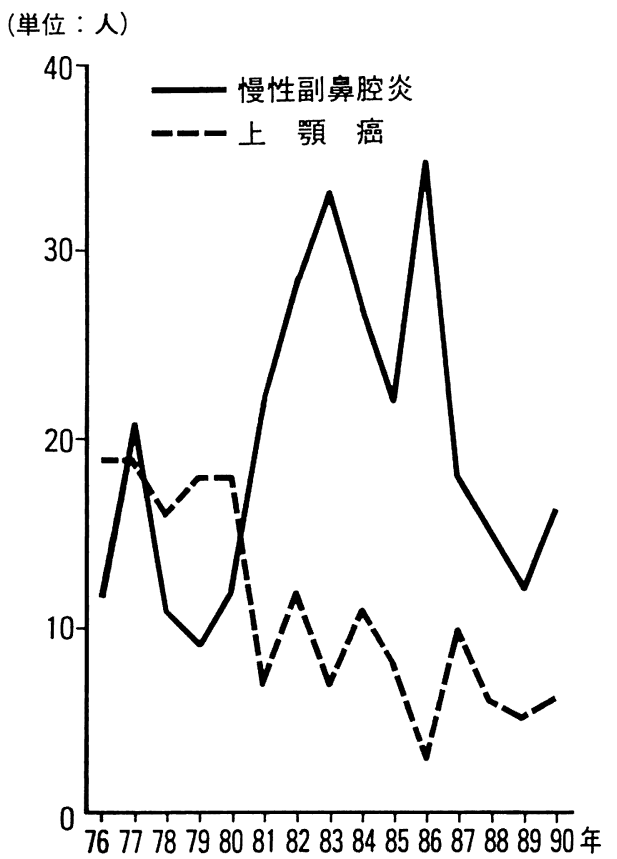

図 6 慢性副鼻腔炎之上顎癌の年次推移 
153名（20.9\%）と最も多く，次いで中耳真珠 腫143名（19.6\%），急性感音難聴136名（18.6 \%), 眩量症103名（14.1\%）と続いていた.

図 7 には慢性中耳炎と中耳真珠腫の年次推移 を示した。これらは共に年々増加傾向にあった。

4) 喉頭疾患

喉頭疾患の入院患者数は男性424名，女性 126 名の合計550名であった。このうち，喉頭癌が 282名（51.3\%） と過半数を占め, 次いで声帯 ポリープ107名 (19.5\%)，急性喉頭炎，蜂窩織 炎などの急性炎症63名（11.5\%）と続いていた。

図 8 に喉頭癌の年次推移をしめしたが，年々 増加傾向にあった。図 9 には喉頭癌の年齢別性 別分布を示したが，男女比では10.8対 1 と男性 に圧倒的に多く，60歳代にピークがあった。 こ れらは諸家の報告399111)12) と同じ傾向であった.

5 ）先天奇形

当科の特色として，小耳症を代表とした先天 奇形に対する形成手術が多いことが上げられる. そのため，先天奇形を一つの疾患分野として独 立させた。

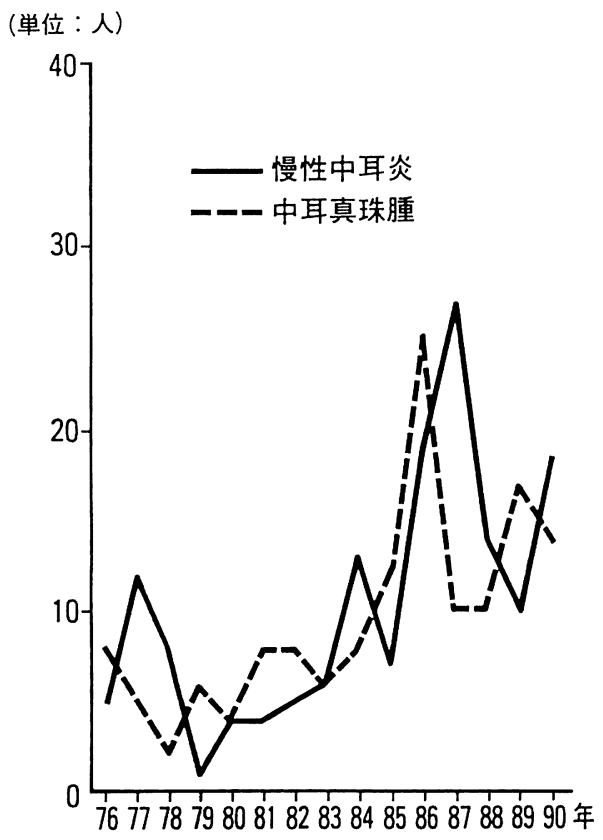

図 7 慢性中耳炎之中耳真珠腫の年次推移
先天奇形の入院患者数は, 男性298名, 女性 177名の合計475名であり，耳介形成術を目的と して入院した小耳症患者が347名（73.1\%）と 最も多かった。この小耳症と唇裂口蓋裂の年次 推移を図10に示した。小耳症は，男性223名， 女性124名と男性に多く，また1978年までは増 加傾向にあった。 また, 男女ともに約 $60 \%$ が右 小耳症という結果であった。

また唇裂，口蓋裂は，男女比は注ぼ同一であ るが，最近は減少傾向にあった。これは口腔外 科で取り扱う比率が高くなった結果と考える.

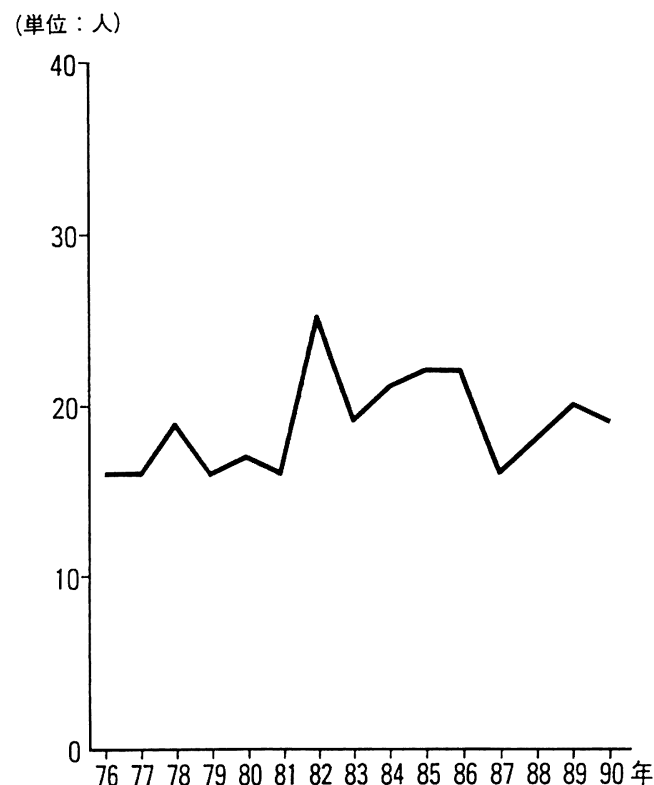

図 8 喉頭癌の年次推移

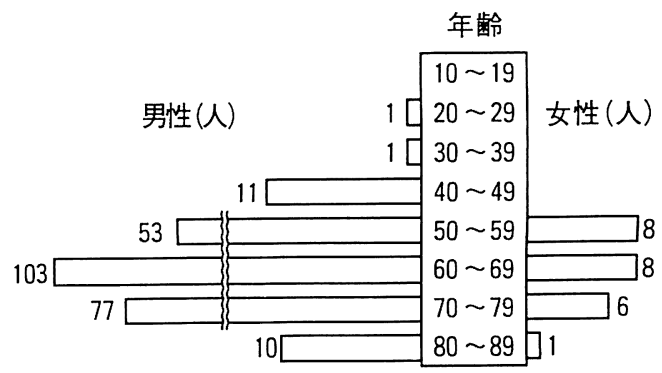

図 9 喉頭癌の年齢別性別分布 
6 ）気管食道疾患

気管食道疾患の入院患者数は, 男性 137 名, 女性80名の合計217名であった。このらち, 気 道異物と食道異物が多く，それぞれの全体の $28.1 \% ， 35.5 \%$ 占めていた。図11に気道異物 と食道異物の年龄分布を示した。

気道異物は，男性44名，女性17名の合計61名 であり，諸家の報告13) 17） と同様に男性が女性 の約 2 倍と多かった. 異物の種類としては, ピー ナツに代表される豆類が48例（78.7\%）と最も 多く，他には義歯 (4 例), 玩具の鉄砲の弾 ( 2 例)，マチ針（2 例）等が見られた。図11に示 したよらに，気道異物はそのほとんどが $0 \sim 4$ 歳に集中しており，また $0 \sim 4$ 歳の53例のうち 45例 $(84.9 \%)$ がピーナツ等の豆類であった。 これも諸家の報告9)13) 17) と同様であった，次 に食道異物であるが，男性40名，女性34名の合 計74名と男性が少し多かったが，男性が女性の 約 2 倍に多いとする諸家14)17) 19) の報告とやや 異なる.異物の種類としては PTP が26例

(単位：人)

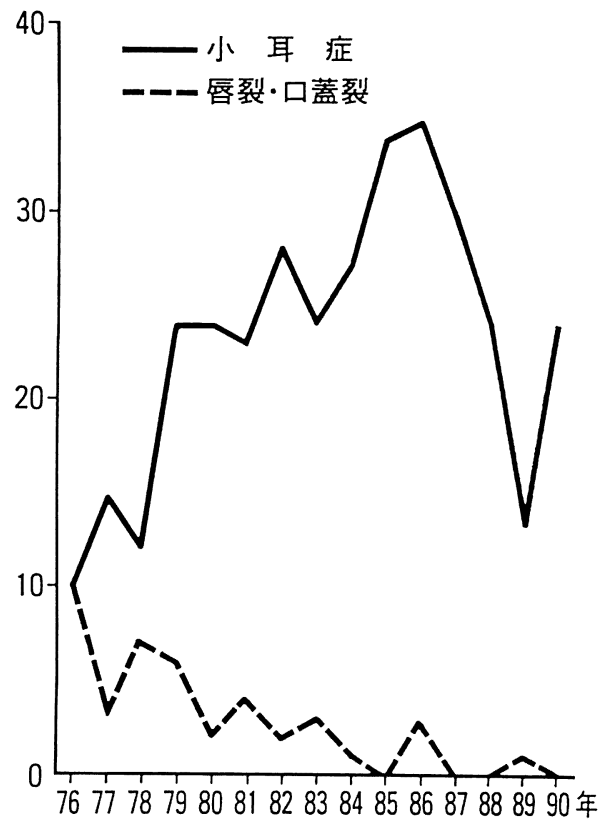

図10 小耳症と唇裂・蓋裂の年次推移
（35.1\%）と最も多く，次いで義歯11例，硬貨 8 例，魚骨 7 例と続いていた，年齢分布は 0 〜 4 歳に最も多かったが，中高年層にも少数なが らほぼ均等に分布していた。 0 〜 歳では硬貨, 画鋲，玩具等が多く，中高年層では PTP と義 歯が多かった。

7）口腔疾患

口腔疾患（口唇を含む）の入院患者数は，男 性122名，女性78名の合計200名であった。この らち，悪性腫瘍が 150 名（75.0\%） と過半数を

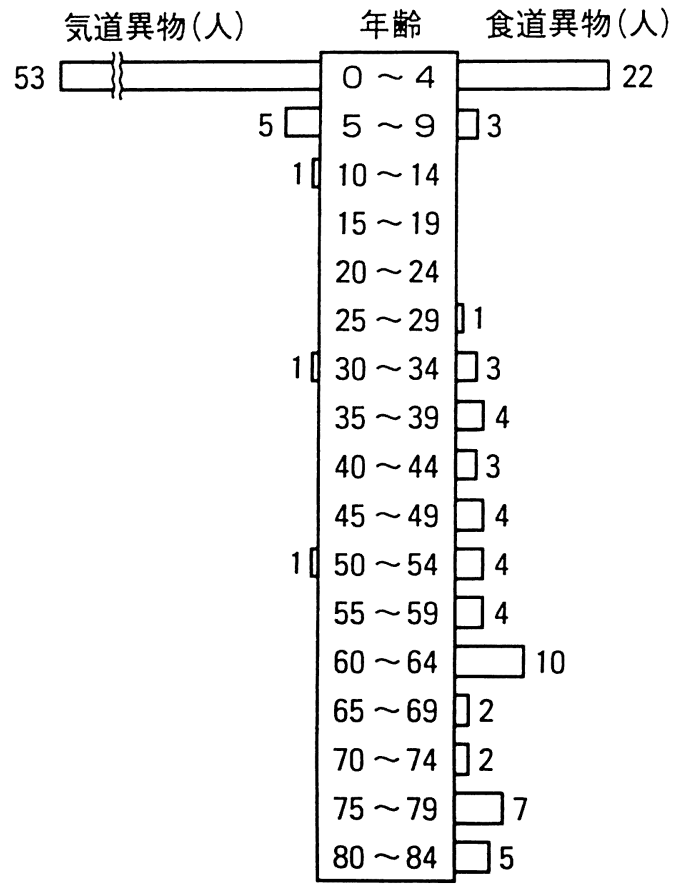

図11 気道異物と食道異物の年㱓別分布

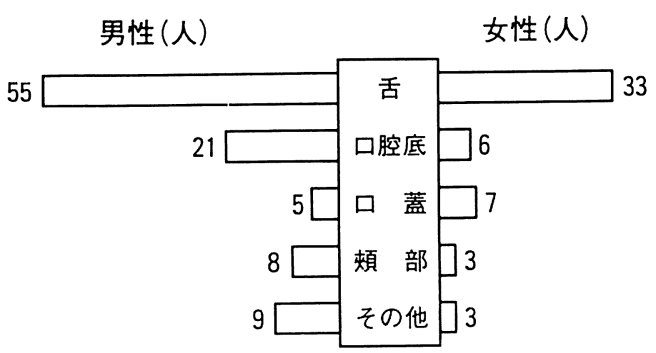

図12 口腔悪性腫瘍の部位別珄別分布 
占め, とりわけ舌悪性腫瘍が88名と多かった。 他の疾患としては良性腫瘍が25名あり，この中 でも舌良性腫瘍が15名と多く, 急性炎症が16名, 外傷が 5 名と続いていた。

図12に口腔悪性腫瘍の部位と男女別を示した が, 舌, 口腔底, 硬口蓋, 頓粘膜の順に多かっ た. 舌悪性腫瘍が口腔悪性腫瘍の過半数を占め るのは諸家20) 22) の報告と同様であった。また， 硬口蓋以外の部位では男性に多かった。

\section{8 ）唾液腺疾患}

唾液腺疾患の入院患者数は, 男性63名, 女性 48名の合計111名であった。耳下腺, 顎下腺の 腫瘍が合計76名例 $(68.5 \%$ ） と過半数を占め, 他には唾石19名, がま腫 2 名等が見られた.

唾液腺腫瘍の良悪性別, 男女別を図13に示し たが，良性腫瘍の方が多く，また，良性腫瘍， 悪性腫瘍ともに耳下腺に多く，これらは諸 家23) 27) の報告と同様であった。

\section{9 ）その他}

その他の疾患では, 顔面外傷が 66 名と最も多 く，他の代表的疾患としては甲状腺腫瘍26名， 頸部リンパ節炎 24 名, 正中頸襄胞 21 名等が見ら れた。$$
\text { まとめ }
$$

1976年 1 月より1990年12月までの 15 年間の入 院患者延4448名について統計的観察を行った.

1. 咽頭疾患が最も多く, 次いで鼻副鼻腔疾 患, 耳疾患, 喉頭疾患, 先天奇形の順であった.

2. 咽頭疾患では, 習慣性アンギーナ, 扁桃 病巣感染症等により, 扁桃摘出術を目的として 入院した患者が最も多かった。また，咽頭覀性

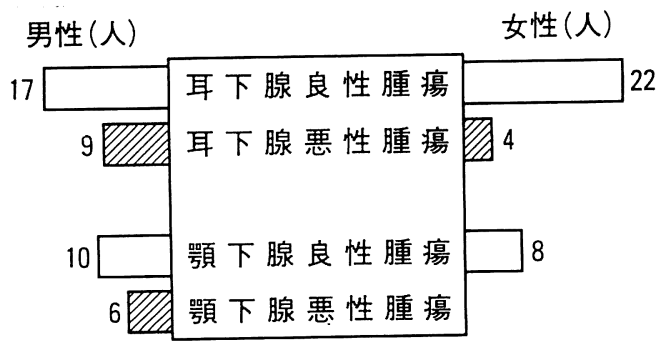

図13唾液腺腫瘍の部位別性別分布
腫瘍の增加傾向が見られた。

3. 鼻副鼻腔疾患では, 上顎癌の減少傾向が 見られた。

4. 耳疾患では, 慢性中耳炎と中耳真珠腫の 増加傾向が見られた。

5. 喉頭疾患では, 喉頭癌の増加傾向が見ら れた。

6. 先天奇形では, 小耳症が多かった.

7. 気管食道疾患ではともに異物が多く, 気 道異物は 4 歳以下の小児に多く, 食道異物は 4 歳以下と60歳代に二峰性のピークを認めた.

8. 口腔疾患では, 悪性腫瘍, 特に舌癌が多 かった.

9. 唾液腺疾患では, 耳下腺, 顎下腺の腫瘍 が多かった。

\section{参考文献}

1）志賀伸之, 小林俊光, 高坂知節 : 東北大学耳鼻 咽嗼科括ける入院患者統計とその推移. 耳鼻 臨床 $80: 1719 \sim 1728,1987$.

2）荒川栄一, 高坂知節 : 我教室六年間の耳鼻咽喉, 頭頸部, 気管食道疾患の年度別推移. 耳鼻 25 : 143 145, 1979.

3）中島恒彦, 松元一郎, 朝隈真一郎, 他: 耳鼻咽 喉科疾患の年度別推移. 耳鼻 $19: 594 \sim 600$, 1973.

4）佐藤博久, 柳下恵子, 持松いづみ, 他：咽頭癌 の死因統計. 耳鼻 $34: 376 \sim 383,1988$.

5）大河内幸男, 小針啓生, 大谷 璇, 他 : 当教室 に打ける上咽頭悪性腫瘍の統計的観察. 耳鼻臨 床 78 增 $1: 976 \sim 982,1985$.

6）真島一彦, 小野 勇, 海老原敏, 他: 中咽頭側 壁悪性腫瑒の臨床像. 目耳鼻 $85 ： 1554 \sim 1561$, 1982.

7）戸田勝也, 小笠原寛, 兵 典子, 他 : 教室にお ける下咽頭癌の治療成績. 耳鼻臨床 補 $4: 47$ 52, 1986.

8）鶴田至宏, 佐藤武男, 宮原 裕, 他: 下咽頭癌 患者死亡例の臨床的検討. 日気食会報 $37: 305$ $\sim 310,1986$.

9）竹内和郎, 大梘好正, 大谷 篇: 当教室28年間 の入院患者統計.耳鼻臨床 78 : 999 1007, 1985.

10）平川勝洋, 田頭宣治, 杉本嘉朗, 他 : 過去 10 年 
間の当教室に打ける上顎覀性腫瘍の統計的観察.

耳鼻臨床 $74: 2104 \sim 2110,1981$.

11）小野勇：疫学的にみた啹頭癌の動向. JOHNS $4: 1171 \sim 1174,1988$.

12）粟田口省吾, 宮野和夫, 円山宏洋, 他: 気管気 管支異物63例の臨床的検討. 日気食会報 31 ： 315 321, 1980.

13）大戸武久, 内田 豊, 遠藤朝彦, 他 : 当教室 10 年間の気道および食道異物の臨床統計的観察.

日気食会報 $32: 241 \sim 248,1981$.

14）仁瓶誠五, 樋渡章二, 大八木章博, 他 : 当院に おける気管気管支異物 10 年間の統計的観察と興 味ある若干例について.耳鼻臨床 $76: 753 \sim 763$, 1983.

15）牧清人, 安岡義人, 原田 紀, 他: 当教室 25 年間の気管, 気管支異物の統計的観察. 耳鼻臨 床 $77: 661 \sim 671,1984$.

16）堤康一朗, 戸田行雄, 飯田 順, 他 : 当教室 10 年間の気道及び食道異物の臨床統計的観察. 耳 鼻臨床 補 $9: 59 \sim 65,1987$.

17）栗山 博, 武田一雄, 高橋宏明, 他 : 大阪医科 大学耳鼻咽喉科に括ける最近 6 年間の食道異物 に関する統計的観察. 日気食会報 $29: 208 \sim 214$, 1978.

18）西條 茂, 郭 安雄, 佐藤雅弘, 他: わが教室 食道異物症例の統計的観察. 耳鼻 $25: 313 \sim 317$,
1979.

19）河辺義孝：口腔の腫瘍一とくに病因と臨床病理 を中心として一. 耳展 $26: 120 〜 127,1983$.

20）田中信三，川口寿郎，平野 実 : 口腔癌治療の 変遷と現状. JOHNS $6: 147 \sim 151,1990$.

21）井本祥子, 藤田豪紀, 金井直樹, 他 : 当教室に 拈ける口腔扁平上皮癌症例の検討.耳鼻臨床 補15:77〜85, 1987.

22）村上政文：唾液腺腫瘍の臨床病理学的および免 疫組織学的研究. 目耳鼻 $91: 247 \sim 261,1988$.

23）寺倉直明, 田中克彦, 吉村 理, 他 : 耳下腺腫 瘍の臨床統計一当教室 10 年間の集計一.耳鼻 $34: 698 \sim 702,1988$.

24）鶴田至宏, 佐藤武男, 宮原 裕, 他: 唾液腺腫 瘍92例の臨床統計. 目耳鼻 $89: 724 \sim 730,1986$.

25）金子敏郎，林崎勝武：唾液腺悪性腫瘍. JOHNS 2 : 403 408, 1986.

26）竹内 亘, 生駒尚秋, 神崎裕士, 他 : 唾液腺腫 瘍57例の臨床的検討.耳鼻 $32: 997 \sim 1002,1986$.

27）金子まどか, 柊 光一, 古川政樹, 他: 耳下腺 腫瘍の統計的観察. 耳鼻 $33: 261 \sim 268,1987$.

(別刷請求先 : 山本真一郎

厂467 名古屋市瑞穂区瑞穂町川澄 1

名古屋市立大学医学部耳鼻咽喉科学教室) 